\title{
Centromochlus meridionalis, a new catfish species from the southern Amazonian limits, Mato Grosso State, Brazil (Siluriformes: Auchenipteridae)
}

\author{
Luisa Maria Sarmento-Soares ${ }^{1,2}$, Fernando G. Cabeceira ${ }^{3}$, Lucélia Nobre Carvalho ${ }^{3,4}$, \\ Jansen Zuanon ${ }^{5}$ and Alberto Akama ${ }^{6}$
}

Centromochlus actually comprises eleven species, being the most problematic genus among the Centromochlinae, including morphologically heterogeneous taxa. The Centromochlus species have a wide distributional area on northern South America. Centromochlus meridionalis, new species, is described from headwaters of rio Teles Pires, contributor of rio Tapajós, Mato Grosso State, Brazil, and represents one of the southernmost records of a centromochlin catfish for Meridional Amazon rivers. Centromochlus meridionalis is promptly distinguished from its congeners by the small orbital diameter (relative to head length), and also by the combination of absence of first nuchal plate, anterior margin of dorsal-fin spine smooth, six branched rays in anal fin, seven pairs of ribs and 34 vertebrae. They are small sized catfishes with adults between 33 to $61 \mathrm{~mm}$ in standard length. The modified male anal fin is conspicuous, with the third unbranched ray enlarged, about twice the width of first unbranched ray. The new species inhabits a region strongly endangered by environmental changes due to expansion of agropecuary activities on Brazilian Amazon, which include this species in an uncertain situation regarding the conservation status of its natural population.

Centromochlus abriga atualmente onze espécies, sendo o gênero mais problemático dentre os Centromochlinae, incluindo táxons morfologicamente heterogêneos. As espécies de Centromochlus apresentam uma ampla área de distribuição no norte da América do Sul. Centromochlus meridionalis, espécie nova, é descrita para as cabeceiras do rio Teles Pires, formador do rio Tapajós, Mato Grosso, Brasil, e representa um dos registros mais ao sul de um bagre centromoclíneo para os riachos da Amazônia meridional. Centromochlus meridionalis é prontamente distinguido de todos os seus congêneres, pelo diâmetro orbital pequeno (em relação ao comprimento da cabeça), e ainda pela combinação da ausência de primeira placa nucal, margem anterior do espinho da nadadeira dorsal lisa, seis raios ramificados na nadadeira anal, sete pares de costelas e 34 vértebras. São bagres de pequeno porte com adultos entre 33 e $61 \mathrm{~mm}$ de comprimento padrão. A nadadeira anal de machos sexualmente maduros é conspicuamente modificada, na qual o terceiro raio indiviso é muito largo, cerca do dobro da espessura do primeiro raio ramificado. O registro desta espécie nova ocorre em uma região fortemente ameaçada por alterações ambientais decorrentes da expansão de atividades agropecuárias na Amazônia Brasileira, a qual coloca esta espécie em uma situação incerta quanto ao estado de conservação da sua população natural.

Key words: Amazon, Centromochlinae, Forest streams, Taxonomy, Teles Pires.

\footnotetext{
${ }^{1}$ Museu de Biologia Prof. Mello Leitão, Av. José Ruschi, 4, Centro, 29650-000 Santa Teresa, ES, Brazil. ${ }^{2}$ Programa de Pós-Graduação em Biologia Animal - Universidade Federal do Espírito Santo. Av. Marechal Campos, 1468, Prédio da Biologia, Câmpus de Maruípe, 29043-900 Vitória, ES, Brazil. luisa@nossosriachos.net

${ }^{3}$ Programa de Pós-Graduação em Ecologia e Conservação da Biodiversidade, Universidade Federal de Mato Grosso - Câmpus Universitário de Cuiabá. fernando.cabeceira@gmail.com

${ }^{4}$ Universidade Federal de Mato Grosso, Instituto de Ciências Naturais, Humanas e Sociais, Câmpus Universitário de Sinop, 78557-267

Sinop, MT, Brazil. carvalholn@yahoo.com.br

${ }^{5}$ Instituto Nacional de Pesquisas da Amazônia- INPA - Coordenação de Biodiversidade. jzuanon3@gmail.com

${ }^{6}$ Museu Paraense Emílio Goeldi, Campus de Pesquisa, Coordenação de Zoologia. aakama@gmail.com
} 


\section{Introduction}

Centromochlus is a member of the Auchenipteridae, and together with Gelanoglanis, Glanidium, and Tatia compose the Centromochlinae (Ferraris, 2007). The genus Centromochlus was designated by Kner (1858) based on Centromochlus megalops and Centromochlus aulopygius. Posteriorly, Bleeker (1862) selected C. megalops as the type species of the genus, with Centromochlus aulopygius being posteriorly ascribed to Tatia by Miranda Ribeiro (1911).

Centromochlus nowadays harbors ten species occurring in northern South America drainages: C. altae Fowler, 1945, C. concolor (Mees, 1974), C. existimatus Mees, 1974, C. heckelii (Fillipi, 1853), C. macracanthus Soares-Porto, 2000, C. punctatus (Mees, 1974), C. reticulatus (Mees, 1974), C. romani (Mees, 1988), C. perugiae Steindachner, 1883 and $C$. schultzi Rössel, 1962. Its distribution ranges from the Orinoco, in Venezuela and Colombia, upper Amazon in Ecuador, lowland Amazon to upper rio Xingu and rio Tocantins basins in central Brazil, as well as northern coastal rivers from the Essequibo (Guyana) to Amapá State and Marajó Island in northern Brazil (Soares-Porto, 1998; Ferraris, 2003, 2007; Akama \& SarmentoSoares, 2007). Centromochlus is the most problematic genus within Centromochlinae. Although Soares-Porto (1998) stated Centromochlus (plus Gelanoglanis) as a monophyletic clade, the derived features for its recognition (e.g., absence of first nuchal plate and ventrolateral process of lacrimal extended, forming anterior portion of orbital margin) assume reversals or multiple state characters on the parsimony analysis. Birindelli (2010) stated that Centromochlus includes species much heterogeneous in morphology, with some species more similar to other centromochline genera. Two species, C. musaicus (Royero, 1992) and C. simplex Mees, 1974, were validated as incertae sedis species in Centromochlinae (Sarmento-Soares \& Martins-Pinheiro, 2008), and C. steindachneri Gill, 1870, was considered a synonym of $C$. heckelii, and needs further investigation regarding its identity (LMSS, pers. obs.). The genus Centromochlus can be distinguished from remaining centromochlin catfishes by an elongated maxilla (also present in Gelanoglanis species) and a ventral keel on cranial base (Soares-Porto, 1998; Birindelli, 2010).

The rio Teles Pires, together with rio Juruena, are tributaries of the clear-water rio Tapajós. The rio Tapajós basin crosses the Brazilian states of Mato Grosso and Pará, extending over more than $900 \mathrm{~km}$ since headwaters to its mouth into the rio Amazonas, at Santarém, Pará. The aquatic ecorregion Tapajós-Juruena includes the upper reaches of rio Tapajós, upstream from the confluence of rios Juruena and Teles Pires, to the middle stretch, where it receives the rio Jamanxin (Barthem et al., 2003). The rio Tapajós headwaters are inhabited by a characteristic fish fauna, mostly endemic, represented by small catfishes, characins and electric fishes
(Netto-Ferreira et al., 2009; Zanata et al., 2009; Campos-daPaz, 2002; Vari et al., 2012).

During recent fieldwork in the headwater streams of rio Teles Pires, in the Municipality of Claudia, Mato Grosso State, a small distinctly colored auchenipterid catfish was found, with distinctive blunt snout and body shape, which is described herein and represents the southernmost record of a Centromochlus species in the Brazilian Amazon.

\section{Material and Methods}

Osteological features were examined in cleared and stained (c\&s) specimens prepared according to the procedures of Taylor \& Van Dyke (1985). Prior to clearing and staining, specimens were dissected when possible to determine gut contents, sexual maturity of gonads, and to check for myological characteristics. Osteological data from some species poorly represented in ichthyological collections were obtained from radiographs (noted as " $R$ " in the Examined Material section). Nomenclatures of osteological elements are based on Fink \& Fink (1981), Arratia (2003), and on suggestions by Britto (2002:13) and Birindelli (2010:29). Most names are explained in The Zebrafish Information Network (ZFIN). Muscle names follow Sarmento-Soares \& Porto (2006). Drawings were rendered from camera lucida or digital photographs preferably of cleared and stained specimens.

Straight-line measurements were made with a digital caliper, and recorded in tenths of a millimeter, based on Sarmento-Soares \& Martins-Pinheiro (2008).

Counts of fin rays and bony elements were obtained from alcohol-preserved and c\&s specimens. Vertebral counts included all rib-bearing centra plus five anterior, complex centrum elements without ribs, and also including the compound caudal centrum $(\mathrm{PU} 1+\mathrm{U} 1)$ as the last element. Count of branchiostegal rays were done only in c\&s specimens. "Centromochlus" musaicus and "Centromochlus" simplex were ranked as incertae sedis species in Centromochlinae by Sarmento-Soares \& MartinsPinheiro (2008). These two species are herein assigned with the generic epithet under quotation marks (“").

Institutional abbreviations are as follows: American Museum of Natural History, New York (AMNH); Illinois Natural History Survey, University of Illinois, Champaign (INHS); Instituto Nacional de Pesquisas da Amazônia, Manaus (INPA); Museu de Biologia Professor Mello Leitão, Santa Teresa (MBML); Museu Nacional, Rio de Janeiro (MNRJ); Museu de Zoologia da Universidade de São Paulo, São Paulo (MZUSP); Netherlands Centre for Biodiversity Naturalis (formerly Rijksmuseum van Natuurlijke Historie), Leiden (RMNH. PISC); Universidade Federal do Tocantins, Porto Nacional (UNT) and National Museum of Natural History, Smithsonian Institution, Washington D.C. (USNM). 


\section{Results}

\section{Centromochlus meridionalis, new species \\ Figs. 1-2}

Holotype. INPA 39684, 40.2 mm SL, Brazil, Mato Grosso, Cláudia, córrego Loanda, a small tributary of rio Roquete, rio Teles Pires

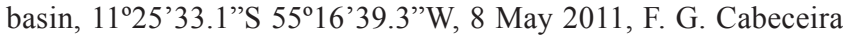
\& E. Barbosa.

Paratypes. Brazil, Mato Grosso State, rio Teles Pires basin: MNRJ 40699, 2, 32.9-40.5 mm SL, MNRJ 40700, 1 c\&s, 38.7 mm SL, INPA 37893, 10, 40.4-47.9 mm SL and INPA 37897, 2 c\&s, 29.7-39.2 mm $\mathrm{SL}$, córrego Loanda, a small tributary of rio Roquete, $11^{\circ} 25^{\prime} 33.1^{\text {''S }}$ 55¹6’39.3"W, 8 May 2011, collected with holotype. INPA 37895, 1, $41.7 \mathrm{~mm}$ SL, MNRJ 40701,1, $51.8 \mathrm{~mm}$ and UNT 12385, 1, $52.3 \mathrm{~mm}$ SL, municipality of Cláudia, córrego Loanda, a small tributary of rio Roquete, 11²5'33.1”S 55¹6’39.3”W, 24 Jul 2010, F. G. Cabeceira, W. S. de Moraes \& J. Dambroz. INPA 37896, 1, 38.6 mm SL and UNT 12386, 2, 35.8-38.7 mm SL, Municipality of Cláudia, córrego Loanda, a small tributary of rio Roquete, $11^{\circ} 25^{\prime} 42.7^{\prime \prime} \mathrm{S} 55^{\circ} 16^{\prime} 34.6^{\prime \prime} \mathrm{W}, 9$ May 2011, F. G. Cabeceira \& E. Barbosa. INPA 37895, 1, 41.7 mm SL and MNRJ 40701, 1, $51.8 \mathrm{~mm}$ SL, Municipality of Cláudia, córrego Loanda, a small tributary of rio Roquete, $11^{\circ} 25^{\prime} 33.1^{\prime \prime S} 55^{\circ} 16^{\prime} 39.3^{\prime \prime W}$, 24 Jul 2010, F. G. Cabeceira, W. S. de Moraes \& J. Dambroz. MBML 5616, 1 c\&s, 39.1 mm SL, MBML 5617, 3, 32.2-46.2 mm SL, MNRJ 40702, 3, 32.6-38.3 mm SL, Municipality of Cláudia, córrego Loanda, a small tributary of rio Roquete, $11^{\circ} 25^{\prime} 33.1^{\prime \prime S} 55^{\circ} 16^{\prime} 39.3$ ”W, 8 May 2011, F. G. Cabeceira \& E. Barbosa. MBML 5615, 2, 49.2-49.7 mm SL and UNT 12387, 1, 39.8 mm SL, Municipality of Cláudia, córrego Loanda, a small tributary of rio Roquete, $11^{\circ} 25^{\prime} 33.1^{\prime \prime} \mathrm{S} 55^{\circ} 16^{\prime} 39.3$ 'W, 8 May 2011, F. G. Cabeceira \& E. Barbosa. MBML 5618, 1, 61.6 mm SL, and UNT 12388, 1, $41.8 \mathrm{~mm}$ SL, Municipality of Cláudia, affluent of córrego Loanda, tributary of rio Roquete, $11^{\circ} 25^{\prime} 48.7^{\prime \prime S} 55^{\circ} 20^{\prime} 16.3$ ”'W, 6 May 2011, F. G. Cabeceira \& E. Barbosa. INPA 37894, 48.3 mm SL, MBML 5614, 2, 43.9-57.2 mm SL and MNRJ 40698, 1, 42.5 mm SL, Municipality of Cláudia, rio Renato, 200 meters upstream from confluence with a small tributary, $11^{\circ} 35^{\prime} 59.1^{\prime} \mathrm{S} 55^{\circ} 15^{\prime} 21.0^{\prime} \mathrm{W}, 21$ May 2011, F. G. Cabeceira \& E. Barbosa. MCP 32975, 6, 29.3-46.4 mm SL, Municipality of Sinop, Ribeirão Macuco, on road BR-163, about $74 \mathrm{Km}$ north from Sinop.

Diagnosis. Centromochlus meridionalis is distinguished from all congeners by having eye diameter less than $16 \%$ of Head Length (vs. 20-35\%). The new species differs from C. heckelii, C. existimatus, C. altae, and $C$. perugiae by absence of anterior nuchal plate (vs. presence). It is distinguished from C. concolor, C. reticulatus, C. macracanthus, C. punctatus, and C. schultzi, by having smooth anterior margin of dorsal spine (vs. with serrae). From $C$. romani by a trapezoid quadrate, with metapterygoid in contact with hyomandibula (vs. enlarged quadrate, interposed between metapterygoid and hyomandibula). Further distinguished from $C$. heckelii and C. existimatus by pectoral-fin spine $20-25 \%$ of SL (vs. 29-42\%) and 6 branched anal-fin rays (vs. 4 or 5). The new species is also distinguished from all congeners, except $C$. perugiae and $C$. romani, by having male modified anal fin with enlarged third unbranched ray, about twice thicker than first unbranched ray.

Description. Measured adult specimens 32.6-61.6 mm SL; morphometric data in Table 1. Body stout when compared to other centromochlines. Head large, robust, slightly depressed; outline of head in dorsal view elliptic, broader than long. Trunk from dorsalfin base to caudal peduncle gradually compressed. Lateral profile of head from snout tip to opercular margin slightly convex until pectoral-fin insertion. Ventral profile of head and abdomen almost flat. Ventral profile of body gently curved, concave behind anal-fin origin. Head integument thin, cranial roof visible; well-developed adipose eye lid; eye latero-dorsally located in anterior portion of head; mouth terminal, upper lip extended postero-laterally as well-developed fleshy rictal fold; snout margin rounded in dorsal view; anterior nostril tubular, located on anterior border of snout; posterior nostril somewhat larger, rounded, limited by small skin flap; transverse distance between anterior nostrils proportionally shorter than distance between posterior ones. Maxillary barbel short, extending posteriorly close to membranous border of opercle; mental barbel short, tip extending to pectoral-fin base, arranged in arc along ventral surface of jaw; inner mental barbel about two-thirds of length of outer mentals. Posterior process of cleithrum short, almost reaching vertical through insertion of dorsal fin spine.

Rostral border of cranium with mesethmoid longer than broad; premaxilla underneath with synchondral articulation; elliptical cranial fontanel, with irregular narrow opening between mesethmoid and frontals (Fig. 3). Nasal ossified as short tubular bone canal, lying between mesethmoid cornua and lateral ethmoid, not sutured to mesethmoid. Autopalatine as a rod, oriented almost parallel to longitudinal axis of body; maxilla very small, less than half the size of autopalatine; vomer short, with arrow-shaped lateral process. Jaws of equal size; premaxilla and dentary narrow with three or four rows of robust conical teeth. First nuchal plate absent; second nuchal plate slightly concave along lateral margins; third nuchal plate thin, projected laterally, with prominent tip. Epioccipital process very small.

Hyomandibula broad, projected anteriorly, connected to both quadrate and metapterygoid through cartilage and deeply dentate suture. Metapterygoid conical, as a wide lamina, joined to quadrate via dentate suture (Fig. 4). Quadrate trapezoidal, with broad base, connected to preopercle, hyomandibula and metapterygoid; long preopercle ventral margins sutured to both quadrate and hyomandibula; suprapreopercle present as short canal bone; opercle laminate, ornamented and broadly subtriangular. 


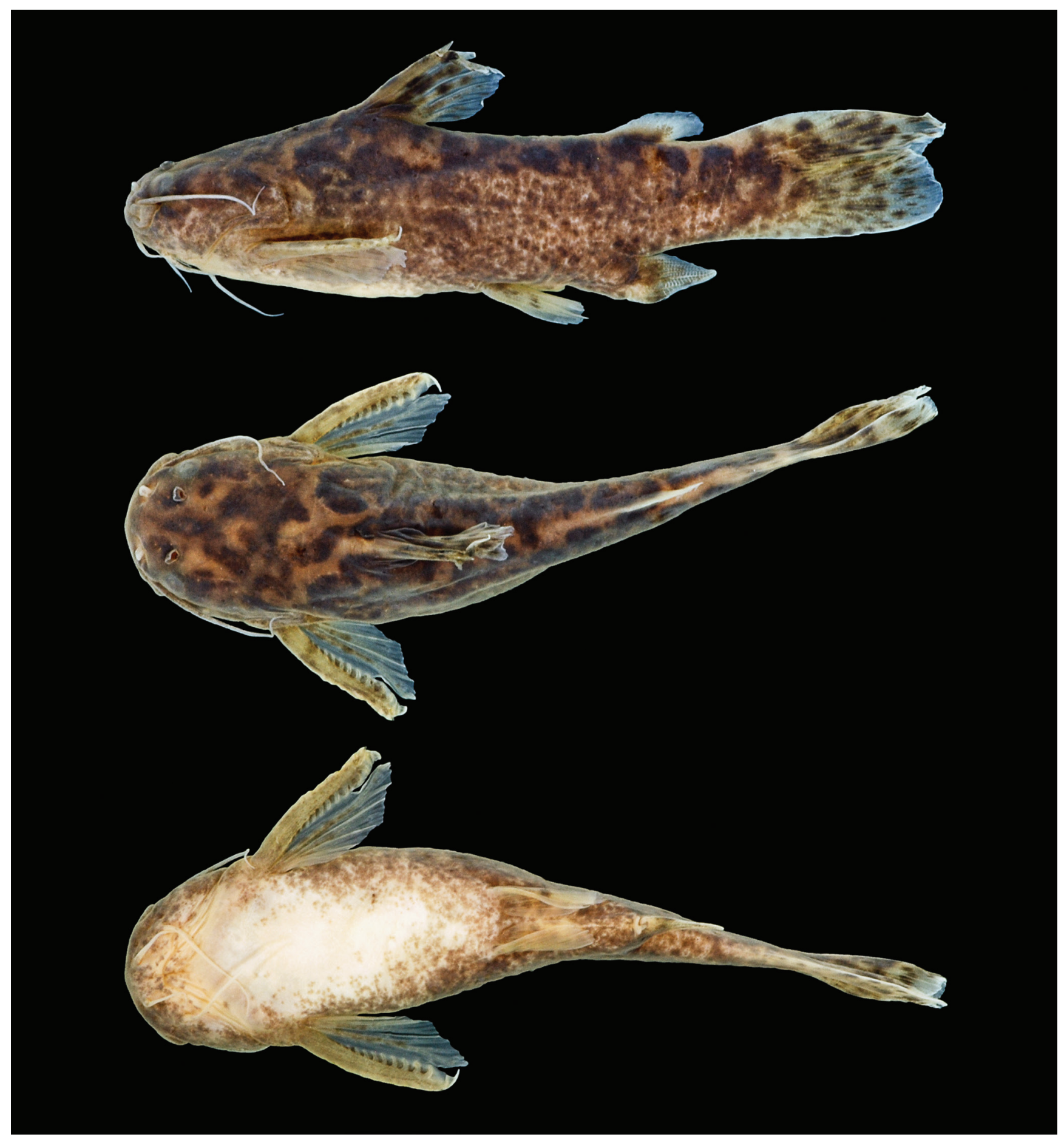

Fig. 1. Centromochlus meridionalis, new species, holotype, INPA 39684, male, $40.2 \mathrm{~mm}$ SL, córrego Loanda, a small tributary of rio Roquete, rio Teles Pires basin, Municipality of Cláudia, Mato Grosso State, Brazil. Lateral, dorsal and ventral views.

Hyoid arch with urohyal reduced with a laminate ventral process; short dorsal hypohyal associated with comparatively large ventral hypohyal; anterior ceratohyal well developed, posterior ceratohyal smaller; branchiostegal ray articulated to hyoid arch; branchiostegal rays 6,3 on anterior ceratohyal, 1 associated with interceratohyal cartilage and 2 posteriormost flattened and associated to posterior ceratohyal.
Branchial (gill) arches with urohyal anterior to basibranchial 2; basibranchial 2 cartilaginous, broadest anteriorly, usually separated by gap from basibranchial 3; basibranchial 3 shorter, forming osseous rod; basibranchial 4 large, flattened and cartilaginous; basibranchial 2 bordered laterally by cartilaginous head of hypobranchial 1; basibranchial 3 between cartilaginous head of hypobranchial 2 and cartilaginous 


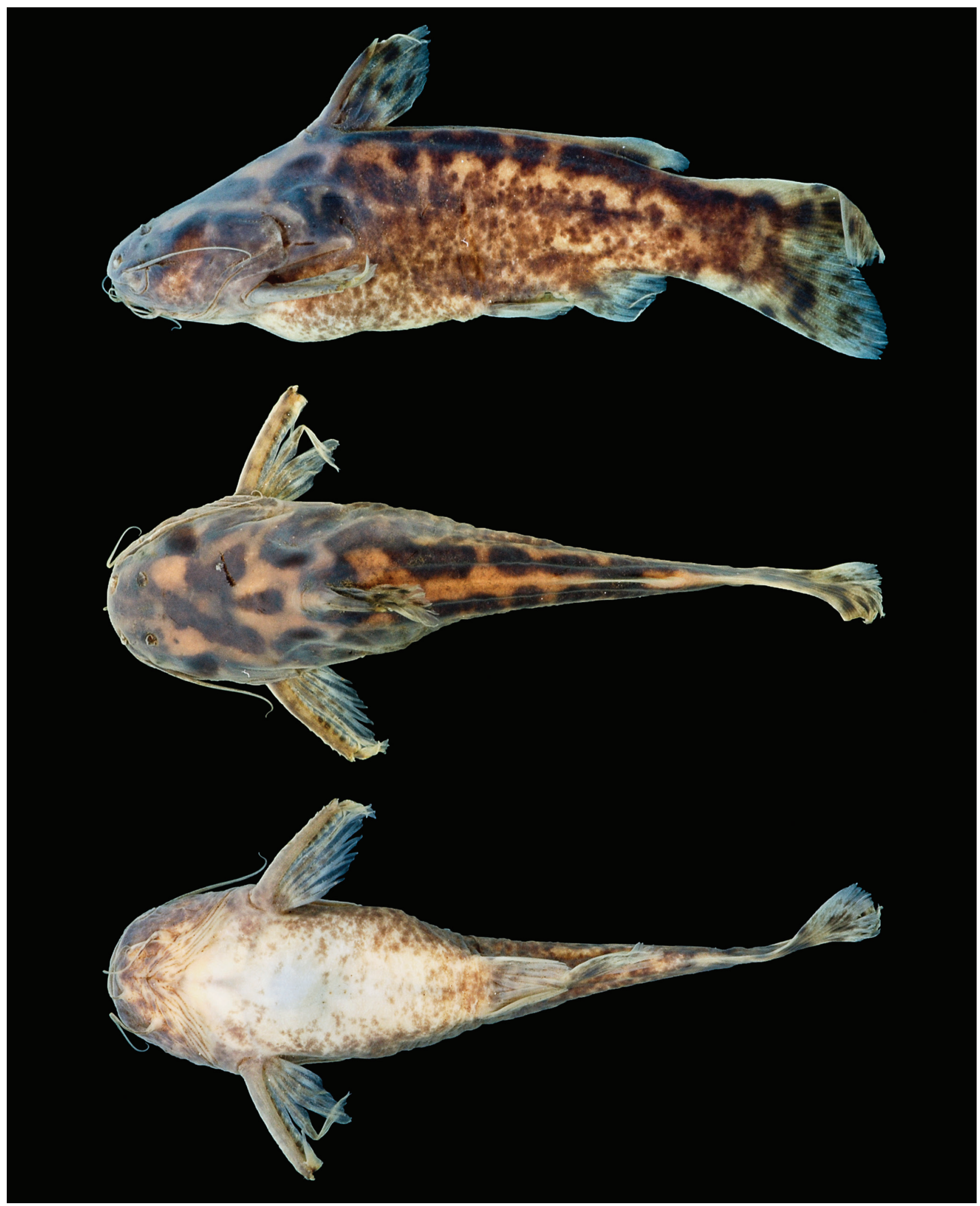

Fig. 2. Centromochlus meridionalis, new species, paratype, INPA 37894, female, 57.2 mm SL, rio Renato, rio Teles Pires basin, Municipality of Cláudia, Mato Grosso State, Brazil, in lateral, dorsal and ventral views. 
hypobranchial 3; basibranchial 4 bordered laterally by cartilaginous head of ceratobranchial 4 and caudally by cartilaginous head of ceratobranchial 5. Hypobranchials 1 and 2 subtriangular, mostly osseous, elongate and expanded laterally, with cartilaginous tips; hypobranchial 3 completely cartilaginous, trapezoidal; hypobranchial 4 absent. Five ceratobranchials, mostly ossified, with cartilage on both ends.
First and second ceratobranchials supporting single row of rakers; third and fourth ceratobranchials with two rows of rakers; fifth ceratobranchial supporting single row of rakers, expanded postero-medially to support lower pharyngeal toothplate with short conical teeth. Four epibranchials, all largely ossified except for cartilaginous ends, supporting one or two rakers each, close to articulation with ceratobranchials.

Table 1. Morphometric data for Centromochlus meridionalis $\mathrm{n}$. $\mathrm{sp} . \mathrm{SD}=$ Standard deviation; $\mathrm{N}=$ Number of specimens examined.

\begin{tabular}{|c|c|c|c|c|c|}
\hline & Holotype & Range & Mean & SD & $\mathbf{N}$ \\
\hline Standard length & 40.2 & $26.6-61.6$ & 40.1 & - & 39 \\
\hline \multicolumn{6}{|c|}{ Percent of Standard Length } \\
\hline Body depth & 24.9 & $20.9-25.8$ & 25.8 & 1.85 & 24 \\
\hline Body width & 24.6 & $22.1-29.1$ & 27.0 & 1.40 & 24 \\
\hline Caudal peduncle depth & 12.2 & $10.2-14.1$ & 12.2 & 0.91 & 24 \\
\hline Caudal peduncle length & 22.9 & $20.9-28.3$ & 23.4 & 1.64 & 24 \\
\hline Predorsal length & 38.3 & $35.0-40.6$ & 37.4 & 1.27 & 24 \\
\hline Preanal length male & 72.1 & $69.6-75.3$ & 72.3 & 1.89 & 11 \\
\hline Preanal length female & & $67.2-72.7$ & 70.0 & 1.67 & 13 \\
\hline Prepelvic length & 53.2 & $50.1-58.3$ & 55.3 & 1.87 & 24 \\
\hline Dorsal origin to pectoral origin & 25.4 & $24.3-31.0$ & 27.9 & 1.61 & 24 \\
\hline Dorsal origin to pelvic origin & 32.6 & $30.2-37.6$ & 34.0 & 1.63 & 24 \\
\hline Pectoral origin to pelvic origin & 34.6 & $31.8-38.8$ & 35.7 & 1.85 & 24 \\
\hline Prepectoral length & 25.6 & $23.0-29.2$ & 26.2 & 1.65 & 24 \\
\hline Dorsal-fin base length & 10.2 & $8.9-13.2$ & 11.2 & 1.01 & 24 \\
\hline Adipose-fin base length & 9.0 & $8.9-14.7$ & 12.0 & 1.52 & 24 \\
\hline Anal-fin base length male & 8.4 & $6.2-8.4$ & 7.8 & 0.88 & 11 \\
\hline Anal-fin base length female & & $8.3-10.2$ & 8.8 & 0.72 & 13 \\
\hline Dorsal-fin spine length & 18.2 & $16.5-23.5$ & 19.0 & 1.64 & 20 \\
\hline Pectoral-fin spine length & 24.6 & $19.8-25.1$ & 22.8 & 1.50 & 20 \\
\hline Posterior process of cleithrum length & 19.4 & $19.1-23.2$ & 20.9 & 1.09 & 24 \\
\hline First branched pelvic-fin ray & 15.9 & $10.4-16.9$ & 13.4 & 1.65 & 22 \\
\hline Longest anal fin ray male & 12.7 & $12.0-14.1$ & 12.9 & 0.85 & 11 \\
\hline Longest anal fin ray female & & $12.9-15.3$ & 14.6 & 1.07 & 13 \\
\hline Maxillary barbel length & 27.6 & $27.6-34.7$ & 30.3 & 1.79 & 18 \\
\hline Outer mental barbel length & 21.2 & $19.0-26.2$ & 22.1 & 1.60 & 18 \\
\hline Mental barbel length & 13.4 & $7.7-15.3$ & 12.7 & 1.66 & 18 \\
\hline Head length & 27.4 & 27.4-31.8 & 29.6 & 1.12 & 24 \\
\hline \multicolumn{6}{|c|}{ Percent of Head Length } \\
\hline Head width & 82.7 & $72.5-82.3$ & 77.5 & 2.45 & 24 \\
\hline Head depth & 42.7 & $40.1-49.0$ & 43.3 & 2.87 & 24 \\
\hline Interorbital distance & 49.1 & $43.1-53.8$ & 47.2 & 2.40 & 24 \\
\hline Left internarial width & 25.5 & $19.7-28.2$ & 22.6 & 2.26 & 24 \\
\hline Anterior internarial distance & 33.6 & $25.0-35.5$ & 30.4 & 2.87 & 24 \\
\hline Posterior internarial distance & 33.6 & $28.2-37.0$ & 32.7 & 2.76 & 24 \\
\hline Snout length & 37.3 & $27.3-39.3$ & 34.1 & 2.87 & 24 \\
\hline Orbital diameter & 12.7 & $11.5-16.4$ & 13.8 & 1.37 & 24 \\
\hline Mouth width & 39.2 & $30.3-40.6$ & 36.9 & 2.87 & 24 \\
\hline
\end{tabular}




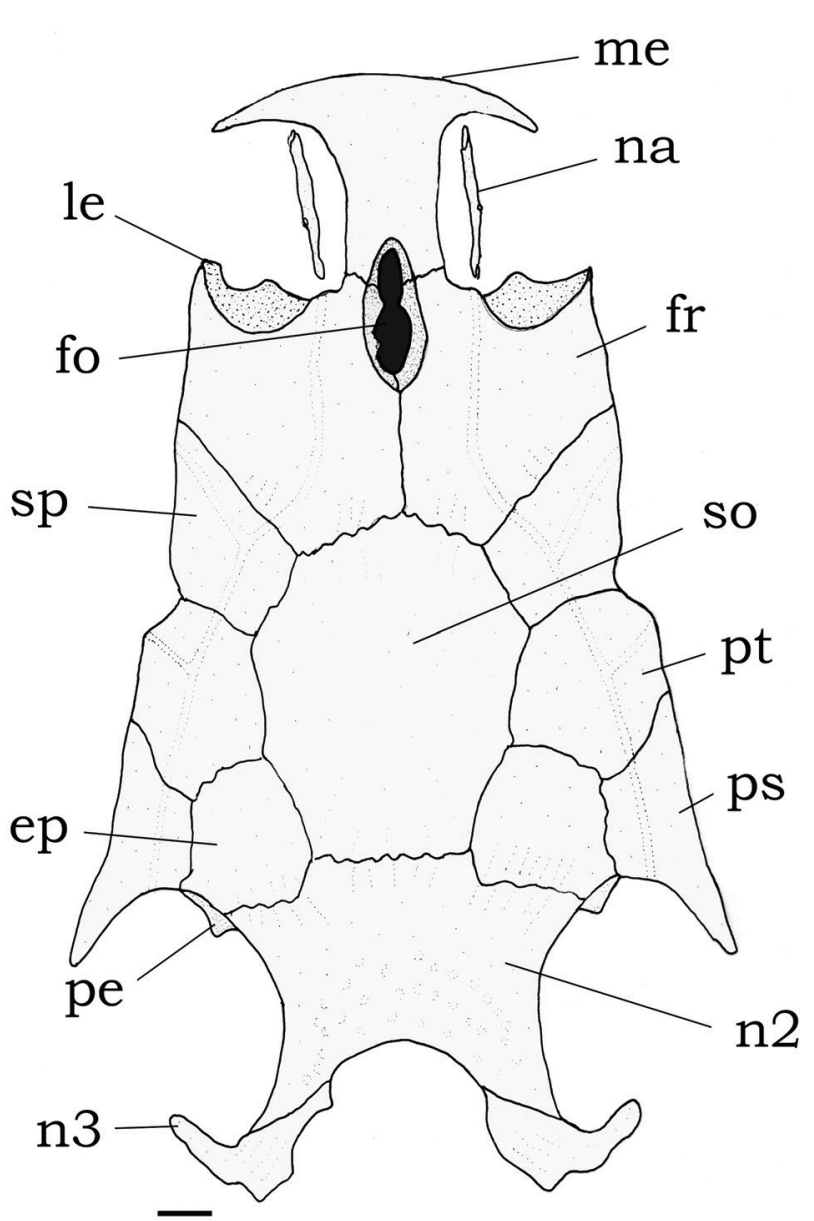

Fig. 3. Neurocranium of Centromochlus meridionalis, MBML 5616, paratype, $39.1 \mathrm{~mm}$ SL. Dorsal view. Abbreviations: ep, epioccipital; fo, cranial fontanel, fr, frontal; le, lateral ethmoid; me, mesethmoid; na, nasal; n2, second nuchal plate; n3, third nuchal plate; pe, posterior epioccipital process; ps, posttemporal-supracleitrum; pt, pterotic; so, supraoccipital; sp, sphenotic. Scale bar $=1 \mathrm{~mm}$.

Epibranchials 1 and 2 rod-like; epibranchial 3 with posterior uncinate process in articulation to epibranchial 4; epibranchial 4 with laminar extension; reduced accessory cartilage, located on angle between cartilaginous ends of epibranchial 4 and ceratobranchial 4. Pharyngobranchial 1 absent; pharyngobranchial 2 short, cartilaginous, somewhat ellipsoid, placed between anteromedial cartilaginous tips of epibranchials 1 and 2; pharyngobranchial 3 elongate, ossified, with expanded posterior border; pharyngobranchial 4 ossified. Upper pharyngeal tooth plate with conical teeth, supported by pharyngobranchial 3 and 4, and also epibranchials 3 and 4 .

Infraorbital 1 with ventro-lateral process restricted to anterior border of eye. Subsequent three infraorbitals thin and canal-like, in complete infraorbital series. Lateral line on body straight, inconspicuous, with ossified canal bones only anteriorly, unbranched at caudal fin.

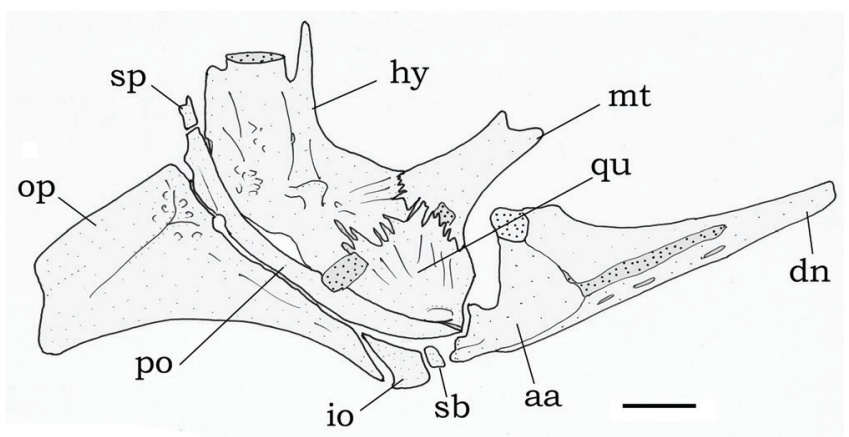

Fig. 4. Right suspensorium of Centromochlus meridionalis, MBML 5616, paratype, $39.1 \mathrm{~mm}$ SL. Lateral view. Abbreviations: aa, angulo-articular; dn, dentary; hy, hyomandibula; io, interopercle; mt, metapterygoid; op,

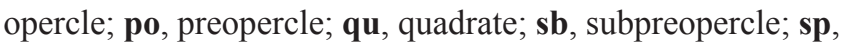
suprapreopercle. Scale bar $=1 \mathrm{~mm}$.

Dorsal fin I,5, dorsal spine smooth anteriorly, posterior margin with minute serrations becoming progressively small towards fin base. Pectoral fin I,5, pectoral spine with 10-16 serrations along entire anterior margin, proximal ones retrorse, distal ones antrorse; 9-10 retrorse serrations along posterior margin; serrations on anterior margin smaller than posterior. Pelvic-fin i,5, margin rounded. Adipose fin small, origin at vertical through anal-fin base. Anal fin iii,6-7; analfin pterygiophores in eight rod-like proximal radials and seven cartilaginous distal radials. Caudal fin deeply forked, lobes with rounded tips, $8+9$ principal rays, 17 upper and 17 lower procurrent rays.

Ribs 7, becoming progressively smaller posteriorly. Total vertebrae $29(\mathrm{~N}=2)$.

Sexual dimorphism. Based on examination of gonads, $C$. meridionalis attains sexual maturity around $30-35 \mathrm{~mm}$ SL. In females a genital papilla is prominent, with a small fleshy tissue around opening. The genital papilla of mature males is visible as an emergent deferent duct (Fig. 5, dd). The anal fin of mature males is strongly modified with all proximal radials basally fused to each other, forming a single ossification. Third unbranched ray elongated and thickened, ending in a rounded tip, together with the slim first branched ray (Fig. 5, uiii, b1). First unbranched anal-fin ray thickened and short. Second unbranched ray elongated, with an intermediate size between the neighboring first and third rays. Third unbranched ray longest, twice the width of first branched ray, bearing 13-15 segments (Fig. 5, uiii, b1). Posterior branched rays progressively shorter; last ray the smallest (Fig. 5, b6). No tegumentary keel preceding the first unbranched anal-fin ray. No modifications observed in the maxillary barbel and in the dorsal spine of males, as is usual in some Auchenipteridae, where transformed males have stiff, ossified maxillary barbels, and an elongated dorsal-fin spine (recent reports in Ferraris \& Vari, 1999; Reis \& Borges, 2006; Ribeiro \& Py-Daniel, 2010). 


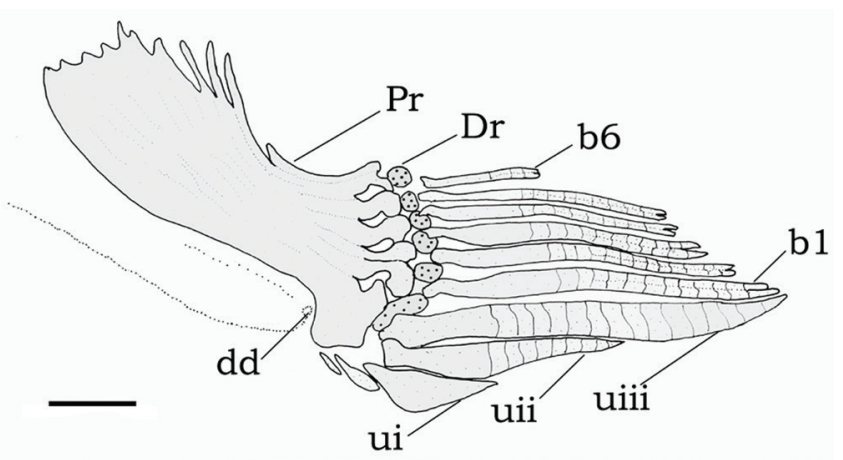

Fig. 5. Male modified anal fin of Centromochlus meridionalis, MBML 5616, paratype, $39.1 \mathrm{~mm}$ SL. Left side lateral view. Abbreviations: b1, branched first ray; b6, branched sixth ray; dd, deferent duct; Dr, distal radials; Pr, proximal radials; ui, unbranched first ray; uii, unbranched second ray; uiii, unbranched third ray. Scale bar $=1 \mathrm{~mm}$.

Color in alcohol. Color dark brown with wavy longitudinal pale bands on dorsal shield and mid-dorsal portions of body; dorsal surface of head and dorsal fin largely dark brown; sides of body with dark brown dots, becoming sparse towards belly. Paired and anal fins pale brown with hyaline tips. Caudal fin hyaline with irregular blackish brown spots.

Live coloration. Body color dark brown mottled in black, in a reticulated pattern, on dorsal shield and mid-dorsal portions of body. Mid-ventral portions of body with scattered brown chromatophores. Fins almost hyaline, where principally the rays are mottled with pale brown spots towards base. Ventral surfaces white somewhat translucent with little scattered brown chromatophores (Fig. 6). Overall body color strongly reminiscent of that of species of Trachelyopterus, possibly due to life style associated to submersed litter banks.

Distribution. Centromochlus meridionalis was recorded so far only from headwater streams of the upper reaches of rio Tapajós, at the rio Teles Pires, Mato Grosso State (Fig. 7). Regarding global biogeographic regionalization of freshwater systems, the new species occurs in the Tapajós-Juruena ecoregion (sensu Abell et al., 2008).

Ecological notes. Centromochlus meridionalis was captured in $1^{\text {st }}$ and $2^{\text {nd }}$ order streams, with 1.22 to $3.16 \mathrm{~m}$ in width and 0.17 to $0.72 \mathrm{~m}$ in depth, characterized by clear water and slow current that varies from 0.15 to $0.36 \mathrm{~cm} / \mathrm{s}$, over sand bottom with litter, and riparian surrounding vegetation (Fig. 8). The fishes were captured under trunks and principally inset somewhat compressed submerged litter banks. It is a micro generalist carnivore that eat small fish (Moenkhausia phaeonota, Characidae), shrimps, aquatic insect larvae and nymphs, fragments of terrestrial arthropods (ants, spiders), seeds and particulate organic matter

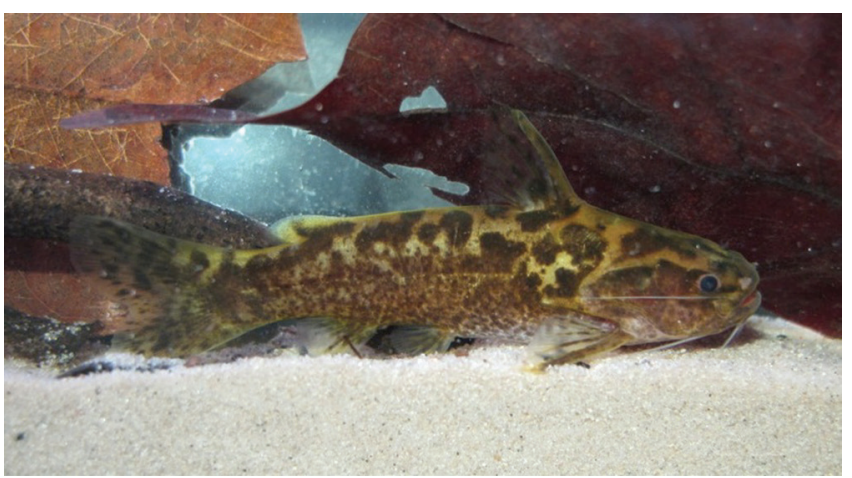

Fig. 6. Centromochlus meridionalis, living specimen photographed in a field aquarium just after collection.

(Cabeceira et al., in prep.). Specimens of Centromochlus meridionalis have nocturnal habits and in aquarium conditions sowed a peak of activity in the evening instead of dusk like other Centromochlinae, and it finds shelter under amidst submerged leaf litter banks before daylight (Cabeceira et al., in prep.). The new species was collected syntopically with Astyanax sp., Bryconops spp., Knodus heteresthes, Moenkhausia spp., Erythrinus erythrinus, Hoplerythrinus unitaeniatus, Rivulus kayabi, Gymnotus aff. carapo, Gymnorhamphichthys petiti, Eigenmannia aff. trilineata, Aequidens sp., Crenicichla inpa, Tatia strigata, Tatia neivai, Helogenes marmoratus, Cetopsis sandrae, small unidentified cetopsid, Hisonotus spp., Cetopsorhamdia sp., Imparfinis aff. stictonotus, Phenacorhamdia somnians, Rhamdia quellen, Ituglanis aff. amazonicus, and Synbranchus sp. (F.G. Cabeceira, unpublished data).

Etymology. The specific name makes reference to the record of a Centromochlus species in southern Brazilian Amazon, a region referred to as "Meridional Amazon". Other Centromochlus species were recorded for southern Amazon, such as C. schultzi from upper Xingu and C. perugiae, from Rondônia and herein registered for southwestern Mato Grosso State.These two species, however, have a wide distributional range, respectively along central brazilian plateau and also western Amazon and upper Paraguay. On the other hand, Centromochlus meridionalis is the single species in the genus originally described from Meridional Amazon, and with distribution apparently restricted to this region.

\section{Discussion}

Reports on the ichthyofaunistic composition of the rio Tapajós are scarce (e.g., Fisch-Muller et al., 2005) and the ichthyofauna of the upper reaches of this basin is still poorly known. Some auchenipterids have been recorded for the Tapajós, including species such as Tocantinsia piresi, Ageneiosus dentatus, Ageneiosus inermis, two new Ageneiosus species, Trachycorystes porosus (Lima \& Ribeiro, 2011; Smerman, 2007; Ribeiro, 2011). Within the centromochlines, Tatia intermedia, 


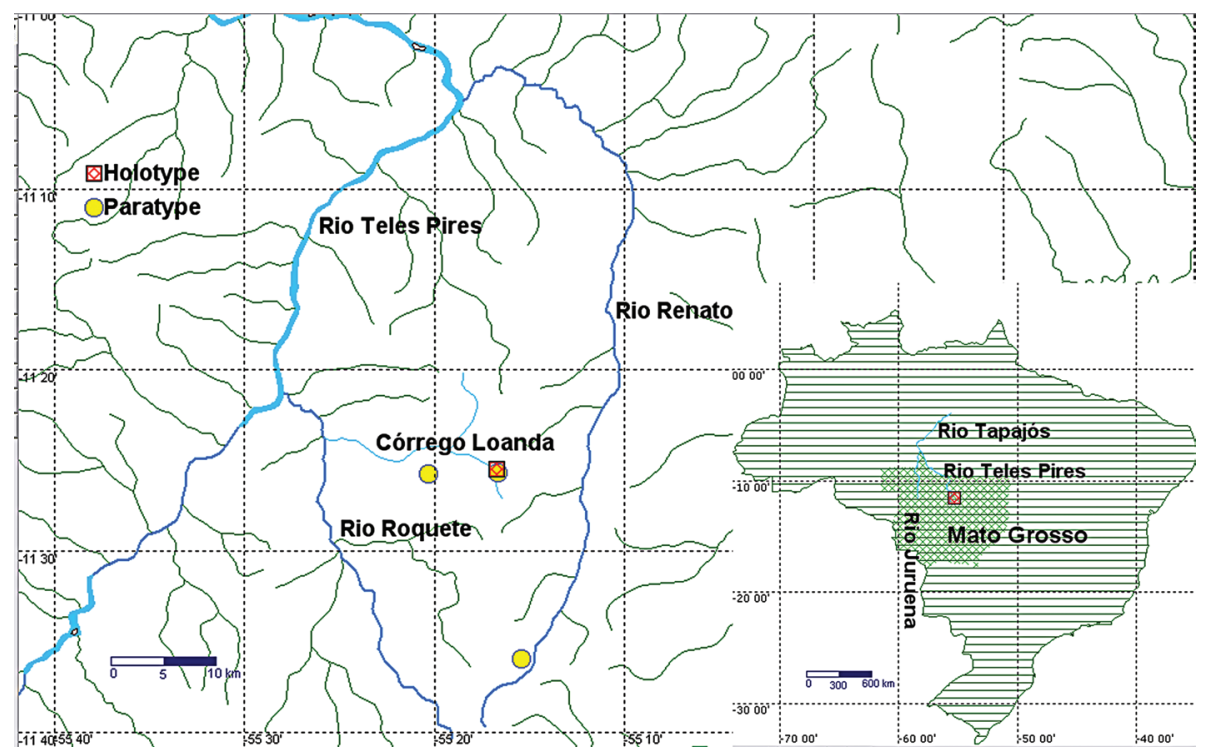

Fig. 7. Map of rio Teles Pires drainage and rio Tapajós headwaters illustrating collecting sites of Centromochlus meridionalis. Red lozenge in square indicates type locality. Yellow circles refer to paratypes localities. Some symbols may represent more than one collecting locality.

Centromochlus heckelii, C. concolor, "Centromochlus" simplex, and Centromochlus sp. (Centromochlus musaicus species group), were found in middle or lower portions of the rio Tapajós basin (Soares-Porto, 1998; Sarmento-Soares \& Martins-Pinheiro, 2008; LMSS, H. Lazzarotto and R. Leitão pers. obs.). The fish fauna of upper Tapajós basin was virtually unknown until recently (Britski \& Lima, 2008). New records for the rio Tapajós upper portions, in the Teles Pires, revealed the presence of the centromochlins Tatia strigata and Tatia neivai (FGC and LMSS, pers. obs.). The new records of Tatia neivai at the rio Teles Pires deserves some comments, as that species is known from upper rio Paraguai, upper rio Paraná and upper rio Paraíba do Sul (Sarmento-Soares \& Martins-Pinheiro, 2008). The presence of

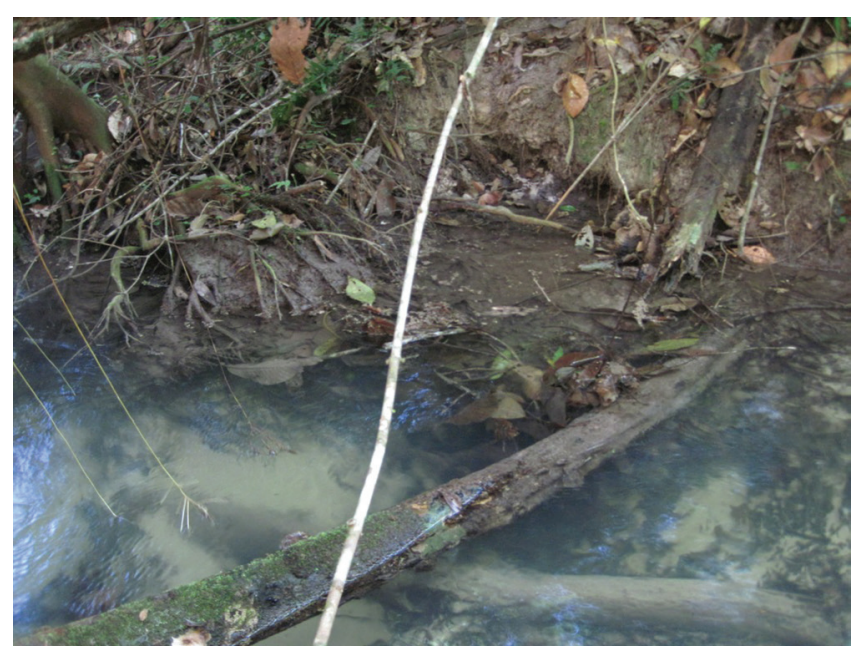

Fig. 8. Detail of córrego Loanda, type locality of Centromochlus meridionalis, rio Teles Pires Basin, municipality of Cláudia, Mato Grosso State, Brazil.
Tatia neivai in headwaters of the rio Tapajós is in accordance with the suggestion of Lima et al. (2007) of a stream capture between headwaters of the Paraguay and Tapajós basins. The presence of such shared species across the divide of these two drainages reinforces biogeographical relationships between the upper rio Tapajós and neighbouring river drainage basins.

Some species of Centromochlus, such as C. heckelii, inhabit medium- to large-sized rivers, where they occupy the upper layer of deep lotic water bodies at dusk and during the night in search of food (mostly arthropods swept by the currents). The new species described herein differs markedly from its congener by occupying small and shallow headwater streams, a kind of habitat predominantly occupied by species of Tatia. In this sense, the combination of a short and stout body, a darkly mottled color pattern, and the use of submerged litter banks for shelter in small headwater forest streams represent unusual characteristics and a considerable extension to the known habits of Centromochlus catfishes.

The new species is herein considered a member of Centromochlus due to the elongated maxilla, extending into the maxillary barbel (a condition also present in Gelanoglanis species), an elongate ventrolateral process of infraorbital 1, forming anterior border of orbit and by a longitudinal crest at the parasphenoid and orbitosphenoid for adductor arcus palatini muscle attachment (Soares-Porto, 1998; SarmentoSoares \& Porto, 2005). Centromochlus meridionalis lacks features that diagnose the other centromochlin genera, such as Tatia, Glanidium, and Gelanoglanis. In comparison to Tatia, Centromochlus meridionalis lacks the hyomandibula elongated anterodorsally not contacting the narrow metapterygoid ( $v s$. hyomandibula in contact to metapterygoid via dentate suture 
in C. meridionalis) (see Sarmento-Soares \& Martins- Pinheiro, 2008: 499, fig. 2 and Fig. 4). Relative to Glanidium, the new species lacks the first nuchal plate ( $v s$. presence in all recognized Glanidium species) (Sarmento-Soares \& MartinsPinheiro, 2013). In comparison to Gelanoglanis, the new Centromochlus meridionalis differs by the two pairs of mental barbels ( $v s$. single pair in Gelanoglanis), vomer present ( $v s$. absent) and by other diagnostic features stated in Soares-Porto et al. (1999). Centromochlus is under long term revisionary studies (LMSS), and investigation regarding its monophyly it out of the scope of present paper.

The new Centromochlus meridionalis is the first record of the genus at the almost unexplored upper Tapajós reaches. Centromochlus perugiae, from upper Amazon, was recently recorded for the rio Madeira drainage and upper rio Paraguay, and represents the morphologically nearest congener to $C$. meridionalis. Both Centromochlus perugiae and $C$. meridionalis have pectoral fin spine anterior margin serrations smaller and more numerous than those on posterior margin; a modified anal fin of mature males with distinctly enlarged third unbranched ray, and also a similar color pattern. Centromochlus perugiae have polygonal blotches over head and flanks, forming a reticulated pattern (vs. pale bands on dorsal shield and mid-dorsal portions of body in C. meridionalis). Although such similarities, C. meridionalis is promptly distinguished by its small eye and arrangement of cranial roof bones. Centromochlus perugiae and Centromochlus meridionalis are possibly closely related, exhibiting similar morphological features and a complimentary distribution patterns, over headwaters of neighboring Amazonian river systems.

The headwaters of the rio Tapajós basin, formed by the rio Juruena and rio Teles Pires, in western Mato Grosso State, have been more intensively sampled for fish only in recent years (e.g., Netto-Ferreira et al., 2009; Zanata et al., 2009). Neighboring headwaters include those of the rio Paraguai to the south and the rio Guaporé to the west. However, there has been little discussion of the biogeographic relationships between the Tapajós and neighboring basins (Carvalho \& Albert, 2011). A relationship between upper rio Tapajós and upper rio Paraguai areas was inferred by Shibatta \& Pavanelli (2005) based on the presence of sister taxa in those basins, evidenced by the distributional patterns of Batrochoglanis melanurus and B. villosus, respectively. The documented cases of shared fish species between upper rio Tapajós and upper rio Paraguai basins occur in the rio Juruena drainage (Carvalho \& Bertaco 2006; Hubert \& Reno, 2006; Lima et al., 2007).

Lundberg et al. (1998) reported headwater-capture events between the upper rio Madeira and rio Paraguai basins, and our results are consistent with this hypothesis (the purported close relation between $C$. perugiae and $C$. meridionalis), and that represent the first report of close related catfish species present in the upper rio Paraguai $(C$. perugiae) and rio Teles Pires drainages (C. meridionalis). The history of the Amazonian aquatic systems and the comprehension about the emergence of such a diversified freshwater fish fauna is still challenging.

\section{Acknowledgments}

We wish to thank our colleagues at the MBML, INPA, and NEBAM for their assistance. We acknowledge Ronaldo F. Martins-Pinheiro for organization of the georefered maps figured and Renildo Ribeiro de Oliveira for the pictures of type specimens. To Henrique Lazzarotto and Raphael Leitão for information regarding a Centromochlus population at Nhamundá, Pará. For loans, exchange of specimens and/or courtesies extended during visits to their institutions we thank Scott A. Schaefer (AMNH), Mike Retzer (INHS), Lucia Rapp Py-Daniel (INPA), Heraldo A. Britski, Osvaldo T. Oyakawa (MZUSP), Paulo A. Buckup, Marcelo R. Britto (MNRJ), Paulo H. F. Lucinda (UNT), Sandra Raredon, Richard P.Vari (USNM) and Martien J.P.van Oijen (RMNH). Specimens of the new species were gathered through fieldwork funded by the Conselho Nacional de Desenvolvimento Científico e Tecnológico with the processes $N^{\circ}$. 569382/2008-4 and 556858/2009-3. We thank Edivaldo Barbosa, Wesley S. de Moraes and Juliane Dambroz for their help in the field. Permission for collecting specimens was granted by ICMBio. JZ receives a productivity grant from $\mathrm{CNPq}$ (proc. 307464/2009-1). LMSS received financial support from the Fundação de Amparo à Pesquisa do Espírito Santo (FAPES).

Material Examined. Centromochlus altae. Colombia. USNM 121965 , 1, $35.5 \mathrm{~mm}$, río Dedo, tributary of río Orteguazo. Centromochlus concolor. Brazil. Pará State. MZUSP 31878, 1, 48.7 mm, rio Tapajós, Alter do Chão. MZUSP 8535, 6, 1 c\&s, 46.5-76.5 mm SL, rio Tapajós, Santarém. Centromochlus existimatus. Brazil. Acre State. MZUSP 48880, 1, $90.2 \mathrm{~mm}$ SL, Porto de rio Branco, rio Branco. Centromochlus heckelii. Brazil. Acre State. MZUSP 48910, 2, 80-83.2 mm, rio Acre between seringal Paraíso and lagoa Amapá. Pará State. MZUSP 8336, 2 c\&s, rio Tapajós, Santarém. Amazonas State. INPA 8203, 2, 73.3-81.8 mm SL, Manacapuru. INPA 10967, 2, 106.2-108.7 mm SL, rio Jamari. Centromochlus macracanthus. Brazil. Amazonas State. INPA 6565, 1, $129.7 \mathrm{~mm}$, rio Negro. MZUSP 30605, 2, 65.7-71.8 mm SL, paratypes, rio Negro, Cachoeira de São Gabriel. Centromochlus perugiae. Brazil. Acre State. MZUSP 31880, 1, 28.2 mm SL, rio Tarauacá, Tarauacá. Mato Grosso State. MCP 15642, 2, 23.1-38.7 mm, Nova Olímpia, córrego cruzando a estrada Tangará da Serra/ Barra do Bugres. Ecuador. MNRJ 30489, 1, 38.5 mm SL, rio Aguari, Napo. Peru. MNRJ 30490, 1, 38.4 mm SL, Huanuco, Amazonas. MZUSP 26029, 2, 22.3-29.8 mm SL, rio Chiriaco, provincia Bagua. MZUSP 26684, 4, 26.2-35.9 mm SL, arroyo de Ivita-Pucallpa, Caserio Neshuya, Provincia Coronel Portillo, Ucayali. Centromochlus punctatus. Brazil. Pará State. INPA 18480, 2, 35.8-37.0 mm SL, rio Tocantins, Tucurui, Igarapé Tucuruizinho. MZUSP 31877, 1, 29.7 mm, rio Itacaiunas, Caldeirão, Cachoeira Carreira Comprida, Serra dos Carajás. Centromochlus reticulatus. 
Guyana. RMNH 26744, 2 R, 18.3- 39.8 mm SL, paratypes, Karanambo, Rupununi. Centromochlus romani. Venezuela. AMNH 91382, 2, 32.5-32.7 mm, rio Siapa, Amazonas. INHS 27999, 1, 27.5-30.9 $\mathrm{mm}$ SL, rio Michay, Apure River drainage, Barinas. Centromochlus schultzi. Brazil. Goiás State. MNRJ 12139, 10 of 38, 1 c\&s, 85.0-108.9 $\mathrm{mm}$ SL, Serra da Mesa dam, upper rio Tocantins, Mato Grosso State. MNRJ 9417, 2, 32.7-60.8 mm SL, upper rio Xingu. "Centromochlus" musaicus Brazil. Amazonas State. MZUSP 9349-9351, 3, 22.8-23.1 $\mathrm{mm}$ SL, rio Jauaperi about $80 \mathrm{Km}$ from mouth. "Centromochlus" simplex Brazil. Mato Grosso State. MZUSP 47506, 1 c\&s, Igarapé do Aeroporto, Humboldt, Aripuanã. Brazil. Pará State. INPA 18475, 1, 19.9 mm SL, rio Tocantins, Jatobal rapids. MZUSP 36862, 2, 28.4-29.6 $\mathrm{mm}$ SL, rio Xingu. MZUSP 82350, 3, 26.2-27.1 mm SL, rio Tocantins. Centromochlus sp. Brazil. Pará State. INPA 35087, 4, 41.8-47.7 mm SL, rio Nhamundá on confluence with Igarapé Jamari-Nhamundá. MZUSP 30585, 6, 35.0-48.4 mm SL, rio Tapajós, near Alter do Chão.

\section{Literature Cited}

Abell, R., M. L. Thieme, C. Revenga, M. Bryer, M. Kottelat, N. Bogutskaya, B. Coad, N. Mandrak, S. C. Balderas, W. Bussing, M. L. J. Stiassny, P. Skelton, G. R. Allen, P. Unmack, A. Naseka, R. Ng, N. Sindorf, J. Robertson, E. Armijo, J. V. Higgins, T. J. Heibel, E. Wikramanayake, D. Olson, H. L. López, R. E. Reis, J. G. Lundberg, M. H. Sabaj Pérez \& P. Petry. 2008. Freshwater Ecoregions of the World: A New Map of Biogeographic Units for Freshwater Biodiversity Conservation. BioScience, 58: 403-414.

Akama, A. \& L. M. Sarmento-Soares. 2007. Família Auchenipteridae. Pp. 116-120. In: P. A. Buckup, N. A. Menezes \& M. S. Ghazzi (Eds.). Catálogo das espécies de peixes de água doce do Brasil. Série livros 23, Museu Nacional, Rio de Janeiro.

Arratia, G. 2003. Catfish head skeleton. An overview. Pp. 20-46. In: Arratia, G., B. G. Kapoor, M. Chardon \& R. Diogo (Eds.). Catfishes. Enfield, Science Publishers Inc.

Barthem, R., E. Ferreira \& M. Goulding. 2003. The Smithsonian Atlas of the Amazon. Washington, D.C. The Smithsonian Institution Press.

Birindelli, J. L. O. 2010. Relações filogenéticas da superfamília Doradoidea (Ostariophysi, Siluriformes). Unpublished Ph.D. Dissertation, Universidade de São Paulo, São Paulo, 387p.

Bleeker, P. P. 1862. Atlas Ichthyologique des Indes Orientales Néêrlandais. 2. Siluroides, Chacoides et Hétérobranchoides. Publié sous les Auspices du Gouvenement Colonial Néêrlandais. J. Smith and Gide, Amsterdam.

Britski, H. A. \& F. C. T. Lima. 2008. ANew Species of Hemigrammus from the Upper Rio Tapajós Basin in Brazil (Teleostei: Characiformes: Characidae). Copeia, 2008: 565-569.

Britto, M. R. 2002. Análise filogenética da ordem Siluriformes com ênfase nas relações da superfamília Loricarioidea (Teleostei: Ostariophysi). Unpublished Ph.D. Dissertation, Universidade de São Paulo, São Paulo, 512p.

Campos-da-Paz, R. 2002. Gymnotus diamantinensis, a new species of electric knifefish from upper rio Arinos basin, Brazil (Ostariophysi: Gymnotidae). Ichthyological Explorations of Freshwaters, 13:185-192.

Carvalho, T. P. \& J. E. Albert. 2011. The Amazon-Paraguay Divide. Pp. 193-202. In: Albert, J. E. \& R. E. Reis (Eds.). Historical Biogeography of Neotropical Freshwater Fishes. Berkeley, University of California Press.

Carvalho, T. P. \& V. A. Bertaco. 2006. Two new species of Hyphessobrycon (Teleostei: Characidae) from upper rio Tapajós basin on Chapada dos Parecis, central Brazil. Neotropical Ichthyology, 4: 301-308.

Ferraris, C. J., Jr. 2003. Family Auchenipteridae (driftwood catfishes). Pp. 470-482. In: Reis, R. E., S. O. Kullander \& C. J. Ferraris Jr. (Eds.). Check List of the Freshwater Fishes of South and Central America. Porto Alegre, Edipucrs.

Ferraris, C. J., Jr. 2007. Checklist of catfishes, recent and fossil (Osteichthyes: Siluriformes), and catalogue of siluriform primary types. Zootaxa, 1418: 1-628.

Ferraris, C. J., Jr. \& R. S. Vari. 1999. The South American genus Auchenipterus Valenciennes, 1840 (Ostariophysi: Siluriformes: Auchenipteridae): monophyly and relationships with a revisionary study. Zoological Journal of the Linnean Society, 126: 338-450.

Fink, S. V. \& W. L. Fink. 1981. Interrelationships of the ostariophysan fishes (Teleostei). Zoological Journal of the Linnean Society, 72: 297- 353.

Fisch-Muller, S., A. R. Cardoso, J. F. P. da Silva \& V. A. Bertaco. 2005. Three new species of Ancistrus Kner (Teleostei: Siluriformes: Loricariidae) from the upper Tapajós and Tocantins rivers. Revue suisse de Zoologie, 112: 559-572.

Hubert, N. \& J.-F. Renno. 2006. Historical biogeography of South American freshwater fishes. Journal of Biogeography, 33: 1414-1436.

Kner, R. 1858. Ichthyologische beiträge. II. Abtheilung. Sitzunberische der Akademie Wissenchaften in Wien, 26: 373-448.

Lima, F. C. T., H. A. Britski \& F. A. Machado. 2007. A new Moenkhausia (Characiformes: Characidae) from central Brazil, with comments on the area relationships between the upper rio Tapajós and upper rio Paraguai systems. Aqua, International Journal of Ichthyology, 13: 45-54.

Lima, F. C. T. \& A. C. Ribeiro. 2011. Continental-Scale tectonic controls of biogeography and ecology. Pp. 145-164. In: Albert, J. E. \& R. E. Reis (Eds.). Historical Biogeography of Neotropical Freshwater Fishes. Berkeley, University of California Press.

Lundberg, J. G. 1998. The temporal context for diversification of Neotropical fishes. Pp. 67-91. In: Malabarba, L. R., R. E. Reis, R. P. Vari, C. A. S. Lucena \& Z. M. S. Lucena (Eds.). Phylogeny and Classification of Neotropical Fishes. Porto Alegre, Edipucrs.

Miranda Ribeiro, A. 1911. Fauna brasiliense. Peixes. Tomo IV (A) [Eleutherobranchios Aspirophoros]. Arquivos do Museu Nacional do Rio de Janeiro, 16: 1-504.

Netto-Ferreira, A. L., A. M. Zanata, J. L. O. Birindelli \& L. M. Sousa. 2009. Two new species of Jupiaba (Characiformes: Characidae) from the rio Tapajós and rio Madeira drainages, Brazil, with an identification key to species of the genus. Zootaxa, 2262: 53-68.

Reis, R. E. \& T. A. K. Borges. 2006. The South American Catfish Genus Entomocorus (Ostariophysi: Siluriformes: Auchenipteridae), with the description of a new species from the Paraguay River Basin. Copeia, 2006: 412-422.

Ribeiro, F. R. V. 2011. Sistemática do gênero Ageneiosus Lacépède (Siluriformes; Auchenipteridae). Unpublished Ph.D. Dissertation, Programa de Pós-Graduação em Biologia de Água Doce e Pesca Interior, Instituto Nacional de Pesquisas da Amazônia, 356 p.

Ribeiro, F. R. V. \& L. H. R. Py-Daniel. 2010. Ageneiosus uranophthalmus, a new species of auchenipterid catfish (Osteichthyes: Siluriformes) from river channels of the central Amazon basin, Brazil. Neotropical Ichthyology, 8: 97-104.

Sarmento-Soares, L. M. \& R. F. Martins-Pinheiro. 2008. A systematic revision of Tatia (Siluriformes: Auchenipteridae: Centromochlinae). Neotropical Ichthyology, 6: 495-542. 
Sarmento-Soares, L. M. \& R. F. Martins-Pinheiro. 2013. Glanidium botocudo, a new species from the rio Doce and rio Mucuri, Minas Gerais, Brazil (Siluriformes: Auchenipteridae) with comments on taxonomic position of Glanidium bockmanni Sarmento-Soares \& Buckup. Neotropical Ichthyology, 11: 265-274.

Sarmento-Soares, L. M. \& M. Porto. 2006. Comparative anatomy of the cheek muscles within the Centromochlinae subfamily (Ostariophysi, Siluriformes, Auchenipteridae). Journal of Morphology, 267: 187-197.

Shibatta, O. A. \& C. S. Pavanelli. 2005. Description of a new Batrochoglanis species (Siluriformes, Pseudopimelodidae) from the rio Paraguai basin, State of Mato Grosso, Brazil. Zootaxa, 1092: 21-30.

Smerman, W. 2007. Ictiofauna de riachos formadores do rio Teles Pires, drenagem do rio Tapajós, bacia Amazônica. Unpublished M.Sc. Dissertation, Universidade Estadual Paulista "Júlio Mesquita Filho", Jaboticabal, 88p.

Soares-Porto, L. M. 1998. Monophyly and interrelationships of the Centromochlinae (Siluriformes, Auchenipteridae). Pp. 331-350. In: Malabarba, L. R., R. E. Reis, R. P. Vari, Z. M. S. Lucena \& C. A. S. Lucena (Eds.). Phylogeny and Classification of Neotropical fishes. Porto Alegre, Edipucrs.

Soares-Porto, L. M., S. Walsh, L. Nico \& J. Netto. 1999. A new species of Gelanoglanis from the Orinoco and Amazon River basins, with comments on miniaturization within the genus (Siluriformes: Auchenipteridae: Centromochlinae). Icthyological Exploration of Freshwaters 10: 63-72.
Taylor, W. R. \& G. C. Van Dyke, 1985. Revised procedures for staining and clearing small fishes and other vertebrates for bone and cartilage study. Cybium, 9: 107-119.

Vari, R. P., C. D. de Santana \& W. B. Wosiacki. 2012. South American electric knifefishes of the genus Archolaemus (Ostariophysi, Gymnotiformes): undetected diversity in a clade of rheophiles. Zoological Journal of the Linnean Society, 165: 670-699.

Zanata, A. M., J. L. O. Birindelli \& C. R. Moreira. 2009. New species of Moenkhausia Eigenmann (Characiformes: Characidae) from rio Xingu and rio Tapajós basins, Brazil, with comments on a putative case of polymorphic Batesian mimicry. Journal of Fish Biology, 75: 2615-2628.

ZFIN Project - Zebrafish Model Organism Database (ZFIN), Zebrafish Anatomical Ontology, University of Oregon, Eugene, OR 97403-5274; World Wide Web URL: Available from: http:// zfin.org/action/anatomy/anatomy-search. (25 August 2012).

Submitted April 4, 2013

Accepted October 7, 2013 by Marcelo Britto Published December 27, 2013 